\title{
DINAMIKA PEDAGANG KAKI LIMA ISLAM DI TENGAH-TENGAH MAYORITAS KRISTEN
}

\author{
Oleh: \\ Rinto Hasiholan Hutapea \\ Email: rintohutapea81@gmail.com
}

\begin{abstract}
:
This paper examines the problem of the dynamics of living conditions of Muslim street vendors in the midst of a Christian majority community in Kupang city. Muslim street vendors in question is a seller of green bean porridge along the road El Tari Kupang city. The research findings show that the root of the problem experienced by Muslim street vendors is the social jealousy shown by the Christian street vendors who are also along the road of El Tari Kupang city. This social jealousy occurs because Christian street vendors see that Muslim street vendors are more successful and successful than they are. Social jealousy extends to racial, ethnic, and religious issues. So that affects the problem of tolerance and harmony of religious people. This research is qualitative. The method used is case study. Data were collected by using in-depth interview technique, observation, and literature study. The conclusion in this study is that Muslim street vendors who previously experienced anxiety and inconvenience in trade, now become comfortable and not experiencing conflict again. Problems and conflicts can be overcome when the government, religious leaders, and the community perform their role well in realizing the harmony and harmony of religious communities.
\end{abstract}

Key words: Muslim street vendors, religious harmony, Christian majority Society.

\section{PENDAHULUAN}

Hidup harmonis dalam masyarakat majemuk adalah dambaan setiap warga Negara di Indonesia. Keanekaragaman suku, agama, dan ras yang ada di Indonesia adalah kekayaan budaya yang mesti disyukuri, bukan ditolak. Fakta keanekaragaman ini sudah semestinya diterima dan dipahami dengan baik oleh segenap insan di tanah air Indonesia ini. Namun kenyataannya tidak semua insan menerima dengan baik perbedaan dan keberagaman yang ada.
Kustini dan Syaiful Arif dalam Jurnal Harmoni menyuguhkan gagasan bahwa mengakui keberagaman dalam praksis pergaulan menjadi tuntutan pada saat ini. ${ }^{1}$ Gagasan ini menegaskan, keberagaman adalah suatu keniscayaan yang harus diakui dan diterima oleh setiap insan yang berada dalam naungan bangsa yang ber-Bhineka Tunggal Ika. Namun dalam realisasinya, masih didapati permasalahan

${ }^{1}$ Kustini dan Syaiful Arif, "Kekristenan dan Nasionalisme di Kota Bogor," Jurnal Harmoni No. 2 Volume 15 (Jakarta: Puslitbang Kehidupan Keagamaan Badan Litbang dan Diklat Kementerian Agama RI Mei-Agustus 2016): 105. Toraja

MARAMPA' Volume 2, Tahun 2017

| Jurnal Lembaga STAKN

183 
dalam memaknai dan mengimplementasikannya. Salah satu aspeknya adalah kegagalan dalam memaknai identitas sosial budaya.

Kegagalan dalam memaknai identitas sosial budaya dapat menjadi pemicu dan penyebab terjadinya konflik di masyarakat. Dalam tulisan Riwanto Tirtosudarmo, dkk, memaparkan bahwa identitas sosial budaya biasanya dipahami berdasarkan ciri-ciri sebagai berikut: ${ }^{2}$ pertama, tempat asal atau kesukubangsaan atau ras (misalnya orang Jawa, orang Cina, orang Arab, orang Belanda, orang Portugis, dan orang campuran atau peranakan). Kedua, keagamaan atau kepercayaan yang dianut (misalnya orang Islam, santri, abangan, orang Kristen, Konghucu, Budha, Hindu, Katolik, kejawen, sunda wiwitan, samin, NU, dan Muhamadiyah). Ketiga, lokalitas yang dikenakan pada kelompok masyarakat tertentu (misalnya orang kampung, orang kota, dll).

Ciri-ciri identitas sosial budaya di atas apabila masyarakat gagal dalam memahaminya, maka akan melahirkan konflik. Kegagalan dalam memahami identitas sosial tersebut dapat dilihat dari sikap yang membeda-bedakan suku dan agama dalam pergaulan sehari-hari di masyarakat. Kecenderungan yang ada di masyarakat umumnya memandang persamaan suku dan agama sebagai perekat hubungan pergaulan. Namun, apabila tidak

\footnotetext{
${ }^{2}$ Riwanto Tirtosudarmo, dkk, Dinamika Sosial di Perkotaan Pantura dan Implikasinya Bagi Indonesia Studi di "Banten" dan "Demak" (Jakarta: LIPI Press, 2010), 8.
}

ada persamaan maka hubungan pergaulan yang erat akan sulit tercapai. Konsep pemahaman ini sudah tentu tidak tepat. Apabila konsep ini terus dibiarkan berkembang akan menjadi parasit yang akan merongrong dan mematikan nilai-nilai keberagaman dan falsafah hidup bangsa yang berBhineka Tunggal Ika.

Permasalahan identitas sosial budaya juga menjadi pokok bahasan dalam penelitian ini. Dimana permasalahan terjadi di kalangan pedagang kaki lima yang ada di sepanjang jalan El Tari kota Kupang, Nusa Tenggara Timur. Permasalahan secara khusus dialami oleh pedagang kaki lima yang beragama Islam. Dimana pedagang kaki lima Islam mengalami ketidakadilan dalam bermasyarakat, serta mengalami ke-gamang-an berada di daerah yang mayoritas masyarakatnya adalah beragama Kristen. Masalah identitas sosial budaya kerapkali menjadi permasalahan antara masyarakat yang beragama minoritas dengan masyarakat yang beragama mayoritas.

Pedagang kaki lima yang dimaksud dalam penelitian ini adalah pedagang bubur kacang hijau. Pedagang kaki lima ini biasa menjajakan dagangannya setiap sore di jalan El Tari kota Kupang. Dari aspek populasi, pedagang kaki lima Islam lebih sedikit dibanding pedagang kaki lima yang beragama Kristen. Dari pengamatan peneliti, pedagang kaki lima penjual bubur kacang hijau yang beragama Islam sebanyak tiga orang. Sedangkan pedagang kaki lima penjual bubur 
kacang hijau yang beragama Kristen sebanyak delapan orang.

Permasalahan pedagang kaki lima yang beragama Islam ini menarik untuk diperhatikan. Penelitian ini secara khusus akan membahas dinamika pedagang kali lima yang bergama Islam. Pertanyaan yang diajukan dalam penelitian ini adalah Bagaimana dinamika hidup yang dialami oleh pedagang kaki lima Islam yang berada di tengah-tengah masyarakat yang mayoritas Kristen? Nilai-nilai apa saja yang dapat menciptakan keberagaman dan toleransi antara pedagang kaki lima Islam dan pedagang kaki lima Kristen? Pertanyaan-pertanyaan ini menjadi fokus kajian dan analisa dalam penelitian ini.

\section{Metode Penelitian}

Penelitian ini menggunakan metode kualitatif. Bentuk penelitiannya adalah studi kasus dengan jenis eksploratif. Pengumpulan data dilakukan selama satu bulan (5 Juni - 5 Juli 2017). Pengumpulan data menggunakan wawancara, observasi, dan studi pustaka. Analisis yang digunakan dalam penelitian ini bersifat deskriptif yang bertujuan untuk membuat suatu gambaran sistematis, faktual, dan akurat mengenai fakta-fakta, sifatsifat, serta hubungan antarfenomena, meskipun tidak bisa dilepaskan dari peran besar peneliti dalam memainkan fungsinya sebagai ciri penelitian kualitatif, dimana peneliti sebagai instrument utamanya. ${ }^{3}$

\footnotetext{
3 Sugiyono, Metode Penelitian Pendidikan Pendekatan Kuantitatif,
}

Informan terdiri dari unsur pedagang kaki lima yaitu pedagang Bubur Kacang Hijau. Informan tersebut terdiri dari pedagang beragama Islam sebanyak 3 orang dan pedagang beragama Kristen sebanyak 8 orang. Lokasi penelitian dipusatkan di sepanjang jalan El Tari kota Kupang yang merupakan jalan utama di kota Kupang. Pedagang yang beraga Islam berada di sekitar pinggir jalan El Tari dekat jalan masuk pasar Inpres. Sedangkan pedagang yang beragama Kristen berada di sekitar jalan El Tari depan Rumah Jabatan Gubernur NTT yang merupakan tempat strategis masyarakat berwisata kuliner.

\section{KAJIAN TEORI}

Kajian teori dalam penelitian ini terdiri atas beberapa penjelasan konsep penting yang diperlukan untuk memperkaya analisa dalam penelitian ini. Penjelasan konsep tersebut mencakup: konsep dinamika kelompok sosial, pedagang kali lima, konflik sosial, fanatisme dan toleransi, pluralisme, serta kerukunan umat beragama. Berikut ulasan dari beberapa konsep tersebut.

1. Dinamika Kelompok Sosial Kata "dinamika" dalam Kamus Besar Bahasa Indonesia (KBBI) memiliki arti gerak; tenaga yang menggerakkan; semangat; dinamika kelompok artinya gerak atau kekuatan yang dimiliki sekumpulan orang dalam masyarakat yang dapat menimbulkan perubahan dalam tata hidup

Kualitatif, dan R\&D (Bandung: Alfabeta, 2016), 305. 
masyarakat yang bersangkutan; dinamika sosial artinya gerak masyarakat secara terus-menerus yang menimbulkan perubahan dalam tata hidup masyarakat yang bersangkutan.

Berkaitan dengan pengertian dinamika tersebut, Abu Ahmadi menjelaskan bahwa perubahanperubahan pada tingkah laku kelompok masyarakat tidak selalu berjalan lancar, tetapi seringkali terdapat hambatan-hambatan, misalnya adanya gejala-gejala vested interest daripada kelompok. Apabila sampai terjadi self interest baik sebagai pribadi maupun kelompok sampai memuncak timbullah persaingan interest, public opini, atau sesuatu undangundang harus dibuat untuk mengubah suatu maksud atau kebijakan politik pemerintahan. ${ }^{4}$

Penjelasan pengertian dinamika di atas dapat dirumuskan dalam kesimpulan bahwa dinamika adalah gerak atau kekuatan yang dimiliki sekumpulan orang dalam masyarakat yang dapat menimbulkan perubahan dalam tata hidup masyarakat sebagai akibat dari gejolak-gejolak yang terjadi di masyarakat.

2. Pedagang Kaki Lima

Pedagang kaki lima (PKL) adalah istilah untuk menyebut penjaja dagangan yang melakukan kegiatan komersial di atas daerah milik jalan (trotoar) yang seharusnya diperuntukkan untuk pejalan

4 Abu Ahmadi, Sosiologi Pendidikan (Jakarta: Rineka Cipta, 2007), 89. kaki.5 Pedagang kaki lima yang dimaksud dalam penelitian ini adalah penjual bubur kacang hijau yang ada di sepanjang jalan El Tari Kupang.

3. Konflik Sosial

Definisi konflik secara etimologis berasal dari bahasa Latin, yaitu con yang berarti bersama dan fligere yang berarti benturan atau tabrakan. ${ }^{6}$ Kamus Besar Bahasa Indonesia (KBBI) mengartikan konflik sebagai perselisihan, percekcokan, dan pertentangan. Sedangkan pengertian konflik sosial adalah pertentangan antar anggota atau kelompok dalam masyarakat yang bersifat menyeluruh, disebabkan oleh adanya beberapa perbedaan seperti perbedaan pola budaya, individu, status sosial, kepentingan, dan terjadinya perubahan sosial. ${ }^{7}$

Lebih lanjut, Haidlor Ali Ahmad dalam buku yang berjudul Resolusi Konflik Keagamaan di Berbagai Daerah mengutip penjelasan Lewis A. Coser yang menjelaskan bahwa istilah konflik biasanya merujuk ke suatu keadaan di mana sekelompok orang dengan identitas yang jelas, terlibat pertentangan secara sadar dengan satu atau lebih kelompok lain karena kelompok-kelompok ini mengejar atau berusaha mencapai tujuan-

https://id.wikipedia.org/wiki/Pedagang kaki lima diakses tanggal 04 Agustus 2017

6 Elly M. Setiadi dan Usman Kolip, Pengantar Sosiologi Pemahaman Fakta dan Gejala Permasalahan Sosial (Jakarta: Kencana Prenada Media Group, 2011), 345.

7 Kamus Besar Bahasa Indonesia, (Jakarta: Balai Pustaka, 2005), 587. 
tujuan yang bertentangan. Pertentangan tersebut dapat berupa pertentangan nilai atau klaim terhadap status, kekuasaan/sumber-sumber daya yang terbatas dan dalam prosesnya ditandai oleh adanya pihak-pihak yang terlibat untuk saling menetralisasi, mencederai hingga mengeliminasi posisi/eksistensi lawan. ${ }^{8}$

Secara sederhana konflik sosial dapat didefinisikan sebagai suatu keadaan di mana sekelompok orang, terlibat pertentangan secara sadar dengan satu atau lebih kelompok lain karena berusaha mencapai tujuan-tujuan yang bertentangan.

Ralf Dahrendorf dalam

Robert H. Lauer membedakan konflik ke dalam empat jenis. Keempat jenis konflik tersebut adalah: ${ }^{9}$

a. Konflik peran. Konflik peran adalah suatu keadaan dimana individu menghadapi harapanharapan yang berlawanan dari bermacam-macam peranan yang dimilikinya.

b. Konflik antara kelompok-kelompok sosial.

c. Konflik antara kelompok-kelompok yang terorganisir dan tidak terorganisir.

d. Konflik antara satuan nasional, seperti antar partai politik, antar

${ }^{8}$ Haidlor Ali Ahmad, Resolusi Konflik Keagamaan di Berbagai Daerah (Jakarta: Badan Litbang Kementerian Agama RI, 2014), 16-17.

9 Robert H. Lauer, Perspektif Tentang Perubahan Sosial (Jakarta: Rineka Cipta, 2001), 102.
Negara, atau organisasi internasional.

Faktor penyebab konflik sosial dapat disebabkan oleh beberapa faktor. Berdasarkan beberapa pendapat ahli, penyebab konflik sosial di masyarakat antara lain:

a) Perbedaan pendirian dan keyakinan. Menurut Narwoko dan Suyanto perbedaan pendirian dan keyakinan orang perorangan telah menyebabkan konflik antar individu. ${ }^{10}$

b) Perbedaan kebudayaan. Lebih lanjut menurut Narwoko dan Suyanto bahwa perbedaan kebudayaan tidak hanya akan menimbulkan konflik antar individu, akan tetapi bisa juga antar kelompok. Pola-pola kebudayaan yang berbeda akan menimbulkan pola-pola kepribadian dan pola-pola perilaku yang berbeda pula di kalangan kelompok yang lebih luas. ${ }^{11}$

c) Perbedaan kepentingan. Perbedaan kepentingan merupakan sesuatu yang mengejar tujuan kepentingan masing-masing yang berbeda, dimana kelompok-kelompok akan bersaing dan berkonflik untuk memperebutkan kesempatan dan sarana. ${ }^{12}$

Sementara itu, M. Ridwan Lubis mengungkapkan bahwa dasar

10 J. Dwi Narwoko dan Bagong Suyanto, Sosiologi Teks Pengantar dan Terapan (Jakarta: Kencana Prenada Media Group, 2005), 68.

11 Narwoko dan Suyanto, Sosiologi Teks Pengantar dan Terapan, 68.

12 Astrid Susanto, Pengantar Sosiologi dan Perubahan Sosial (Bandung: Bina Cipta, 2006), 70. 
adanya konflik dapat dilihat dari sudut emosi keagamaan disebabkan karena setiap agama dipahami penganutnya dengan klaim kebenaran (truth claim) dan klaim keselamatan (salvation claim). ${ }^{13}$ Lebih lanjut Lubis menambahkan dengan adanya klaim ini pada dasarnya disebabkan karena pemahaman agama yang masih terbatas, sehingga yang terjadi adalah simplikasi ajaran agama pada halhal yang bersifat simbolik.

\section{Fanatisme dan Toleransi}

Endang Turmudi menuturkan bahwa radikalisme sering dikaitkan dengan fanatisme, karena fanatisme adalah sikap atau tindakan ke dalam yang memperlihatkan keterikatan ideologis atau psikologis seseorang dengan agamanya. ${ }^{14}$ Dalam hal ini orang fanatik akan bertindak dan mempunyai spirit untuk melaksanakan ajaran agamanya sesuai dengan apa yang diperintahkan agama itu.

Lebih lanjut Turmudi menjelaskan bahwa dua aspek atau konsep fanatisme dan toleransi harus dipraktikkan dalam pola yang seimbang, sebab ketidakseimbangan antara keduanya akan menyebabkan ketidakstabilan sosial dalam hal hubungan antar

${ }^{13}$ M. Ridwan Lubis, "Pengambangan Kebijakan Nasional dalam Pengelolaan Kerukunan," Jurnal Harmoni Volume 15 No. 2 (Jakarta: Puslitbang Kehidupan Keagamaan Kementerian Agama RI MeiAgustus 2016): 9.

14 Endang Turmudi, "Melihat Kembali Radikalisme Islam di Indonesia dan Upaya-Upaya Pencegahannya," Jurnal Masyarakat dan Budaya Volume 14 No. 2 (PMB-LIPI 2012): 223. para pemeluk agama. Ketika fanatisme terlalu kuat- sementara toleransi rendah, maka pada diri pemeluk agama akan muncul sikap permusuhan terhadap pemeluk agama lain. Akan tetapi ketika toleransi yang dominan dalam diri mereka, maka eksistensi agama mereka akan melemah, karena dalam situasi ini para pemeluk agama tidak lagi merasa bangga dengan agama yang mereka peluk.

5. Kerukunan umat beragama Pengertian kerukunan umat beragama dalam penelitian ini merujuk pada pasal 1 ayat 1 Peraturan Bersama Menteri Agama dan Menteri Dalam Negeri No. 9 dan 8 Tahun 2006, yang menyebutkan bahwa kerukunan umat beragama adalah keadaan hubungan sesama umat beragama yang dilandasi toleransi, saling pengertian, saling menghormati, menghargai kesetaraan dalam pengamalan ajaran agamanya dan kerja sama dalam kehidupan bermasyarakat, berbangsa dan bernegara di dalam Negara Kesatuan Republik Indonesia berdasarkan Pancasila dan UndangUndang Dasar Negara Republik Indonesia Tahun 1945.

\section{HASIL PENELITIAN}

\section{Sekilas Gambaran Pedagang Kaki Lima \\ Pedagang kaki lima yang adalah penjual bubur kacang hijau dalam penelitian ini berada di sepanjang jalan El Tari kota Kupang. Pedagang kaki lima mencakup pedagang yang}


beragama Islam dan pedagang yang beragama Kristen. Para penjual bubur kacang hijau biasanya mulai menjajakan dagangannya di sore hari sampai malam hari. Penjual bubur kacang hijau yang beragama Islam berada di sekitar pinggir jalan dekat jalan masuk pasar Inpres. Banyaknya pedagang Islam yang menjual bubur kacang hijau adalah 3 orang. Pedagang Islam ini hanya khusus menjual bubur kacang hijau.

Sementara penjual bubur kacang hijau yang beragama Kristen berada di seberang jalan rumah jabatan gubernur Nusa Tenggara Timur. Tempat jualan ini merupakan salah satu tempat dagang yang strategis karena merupakan salah satu tempat masyarakat berkumpul dan santai sore. Penjual bubur kacang hijau yang beragama Kristen sebanyak 8 orang. Selain menjual bubur kacang hijau, pedagang Kristen juga menjual Jagung dan Pisang bakar.

Berdasarkan hasil wawancara dari pedagang dan penjual bubur kacang hijau yang beragama Islam, mengungkapkan bahwa merekalah yang pertama-tama dan yang mulamula menjual bubur kacang hijau. Umumnya penjual bubur kacang hijau yang beragama Islam menekuni pekerjaan mereka sebagai pedagang kaki lima sudah 3-5 tahun. Belakangan ketika dagangan bubur kacang hijau mulai lar1is dan disukai oleh masyarakat barulah pedagang yang Kristen mulai mengikuti. Dengan berjalannya waktu, pedagang Kristen mulai banyak menjajakan dagangan bubur kacang hijau, serta memiliki lokasi atau tempat berdagang yang terpisah dengan pedagang yang beragama Islam.

\section{Faktor Penyebab Konflik Sosial}

Hasil wawancara dengan informan, khususnya pedagang atau penjual bubur kacang hijau yang beragama Islam, mengungkapkan awal mula peristiwa dan konflik yang mereka alami. Konflik yang mereka alami tersebut membuat mereka semakin dewasa dalam menjalani profesi sebagai pedagang kaki lima di tengahtengah masyarakat. Faktor-faktor konflik tersebut penulis rangkum dari hasil wawancara dari informan pedagang Islam. Berikut ini beberapa faktor konflik yang dialami oleh pedagang kaki lima Islam di tengah-tengah masyarakat yang mayoritas beragama Kristen.

Pertama, faktor perbedaan kepentingan. Berdasarkan teori yang ada, perbedaan kepentingan merupakan sesuatu yang mengejar tujuan kepentingan masing-masing yang berbeda, dimana kelompokkelompok akan bersaing dan berkonflik untuk memperebutkan kesempatan dan sarana. Kaitannya dengan penelitian ini, konflik yang terjadi dalam hal memperebutkan kesempatan dan sarana adalah aspek kecemburuan sosial.

Kecemburuan sosial melanda pedagang kaki lima yang beragama Kristen. Dimana pedagang kaki lima Kristen memandang bahwa dagangan bubur kacang hijau milik pedagang kaki lima Islam lebih laris dibeli oleh masyarakat dibanding dagangan bubur kacang hijau orang Kristen. Secara ekonomi, pedagang 
kaki lima Islam lebih sukses dibanding pedagang kaki lima Kristen. Hal ini menjadi konflik di antara para pedagang kaki lima.

Berdasarkan informasi dari informan pedagang kaki lima yang beragama Islam, dulu saat awalawal mereka berdagang dan mulai banyak yang meminati dagangan bubur kacang hijau, mereka sempat mengalami masalah berupa pelarangan dari oknum masyarakat setempat. Kondisi ini tentu tidak nyaman bagi pedagang kaki lima Islam. Namun kondisi ini tidak berlangsung lama. Melalui musyawarah dengan masyarakat dan pemerintahan setempat, pedagang yang beragama Islam dapat menjalankan usahanya kembali dengan nyaman dan di tempatkan di lokasi yang sekarang mereka tempati.

Kondisi konflik yang didasari oleh kecemburuan sosial ini seharusnya tidak boleh terjadi di tengah-tengah masyarakat yang majemuk. Terlebih apabila satu dengan yang lainnya menunjukkan sikap yang saling menghargai kebebasan yang dimiliki oleh pedagang kaki lima Islam maupun pedagang kaki lima yang Kristen. Persaingan antar pedagang adalah sesuatu yang wajar. Apalagi persaingan tersebut didasari oleh persaingan yang sehat, dimana para pedagang berusaha memberikan pelayanan yang terbaik bagi masyarakat yang adalah pembeli.

Berkaitan dengan pelayanan para pedagang kaki lima, hasil pengamatan dan wawancara menunjukkan bahwa terdapat perbedaan pelayanan antara pedagang kaki lima Islam dengan pedagang kaki lima Kristen. Perbedaan utama terletak dari sikap pelayanan kepada pembeli. Peneliti menemukan bahwa pelayanan yang diberikan oleh pedagang kaki lima Islam lebih baik daripada pedagang kaki lima Kristen. Ketika pembeli datang, pedagang kaki lima Islam menyambut pembeli dengan senyuman dan sikap yang ramah. Hal ini pun peneliti alami ketika setiap kali datang untuk membeli bubur kacang hijau sekaligus sebagai stategi untuk mendapatkan informasi dan melakukan wawancara. Sikap yang ditunjukkan oleh pedagang kaki lima Islam ini tidak penulis dapati dimiliki oleh pedagang kaki lima Kristen. Apabila pembeli datang, pedagang kaki lima Kristen menyambut dengan sikap yang biasanya saja. Jarang muncul senyuman dan sapaan ramah dari pedagang kepada pembeli. Dari aspek pelayanan ini mengungkapkan bahwa pedagang kaki lima Islam lebih unggul dibanding pedagang kaki lima Kristen. Kondisi ini juga diperkuat dengan fakta bahwa masyarakat atau pembeli lebih suka membeli bubur kacang hijau milik pedagang kaki lima Islam.

Kondisi pelayanan pedagang kaki lima Islam yang lebih unggul dibanding pedagang Kristen berdampak pada hasil penjualan dagangan bubur kacang hijau. Dari hasil wawancara, umumnya pedagang kaki lima Islam dalam sehari berhasil menjual habis dagangan mereka. Sementara bubur kacang hijau milik pedagang kaki lima 
Kristen tidak pernah habis terjual. Hal ini menunjukkan bahwa dagangan bubur kacang hijau pedagang kaki lima Islam lebih diminati pembeli atau masyarakat dibanding dagangan bubur kacang hijau milik pedagang kaki lima Kristen.

Selain aspek layanan, aspek rasa dan kualitas masakan bubur kacang hijau juga menjadi pertimbangan dari pembeli. Hal ini terbukti dari beberapa orang pembeli yang penulis wawancarai. Informasi tentang rasa dan kualitas masakan juga terungkap dari mulut ke mulut yang tersebar di masyarakat. Dimana pembeli mengungkapkan bahwa bubur kacang hijau pedagang kaki lima Islam lebih enak atau lebih baik daripada bubur kacang hijau buatan pedagang kaki lima Kristen.

Hasil dagangan bubur kacang hijau pedagang kaki lima Islam lebih laris daripada pedagang kaki lima Kristen. Keadaan ini seringkali menjadi pemicu konflik, dimana terjadinya kecemburuan sosial. Terlebih melihat kondisi pedagang kaki lima Islam yang berada di tengah-tengah masyarakat yang mayoritas beragama Kristen. Pedagang kaki lima Islam menghadapi kondisi yang dilematis. Sekalipun demikian, mereka tetap bertahan untuk menjual bubur kacang hijau dengan menjaga sikap dan perilaku mereka supaya tetap baik dan diterima oleh masyarakat.

Kedua, faktor perbedaan pendirian dan keyakinan. Perbedaan pendirian dan keyakinan ini terekspresi dalam sikap fanatisme agama. Turmudi dalam kajian teori menjelaskan bahwa konsep fanatisme dan toleransi harus dipraktikkan dalam pola yang seimbang, sebab ketidakseimbangan antara keduanya akan menyebabkan ketidakstabilan sosial dalam hal hubungan antar para pemeluk agama. Ketika fanatisme terlalu kuat, sementara toleransi rendah, maka pada diri pemeluk agama akan muncul sikap permusuhan terhadap pemeluk agama lain.

Aspek fanatisme menjadi salah satu indikator terjadinya konflik antara pedagang kaki lima Islam dengan pedagang kaki lima Kristen. Hasil wawancara peneliti berkaitan dengan aspek fanatisme ini mengungkapkan bahwa pedagang kaki lima Kristen menganggap bahwa mereka lebih berhak menempati lokasi yang strategis di sepanjang jalan El Tari. Kondisi ini berkaitan dengan fakta pedagang kaki lima yang beragama Kristen adalah penduduk mayoritas dan sekaligus sebagai penduduk asli di kota Kupang. Sementara pedagang kaki lima Islam adalah masyarakat yang minoritas dan sekaligus berstatus sebagai penduduk pendatang di kota Kupang.

Permasalahan atas pemahaman fanatisme ini membuat pedagang kaki lima Islam resah dan tidak nyaman dalam melakukan aktivitasnya. Pedagang kaki lima Islam menyadari bahwa mereka memang penduduk pendatang dan juga dalam hal agama sebagai yang minoritas. Akan tetapi, sebagai warga Negara mereka berhak untuk bekerja apa saja di negeri ini selama itu tidak melanggar hukum. 
Terlebih mereka hanya menjadi pedagang dan penjual bubur kacang hijau dan tidak melakukan sesuatu yang dapat merugikan masyarakat luas. Berdasarkan pemahaman ini, mereka tetap melakukan pekerjaan sebagai tukang bubur kacang hijau bahkan bekerja lebih giat dan memberikan pelayanan yang baik kepada setiap pembeli atau pelanggan.

Bekerja dengan giat dan memberikan pelayanan yang baik kepada setiap pelanggan menjadi modal besar buat pedagang kaki lima Islam untuk bertahan dan tetap eksis berjualan bubur kacang hijau hingga saat ini. Dari hasil pengamatan dan wawancara peneliti menunjukkan bahwa hasil dagangan bubur kacang hijau milik pedagang Islam lebih laris dibanding pedagang Kristen. Pedagang kaki lima Islam yang berjumlah tiga pedagang menuturkan bahwa rata-rata setiap hari bubur kacang hijau yang mereka jual laku dan habis. Sementara itu untuk pedagang kaki lima Kristen rata-rata setiap hari dagangan bubur kacang hijau mereka tidak habis terjual.

Aspek fanatisme agama di atas sudah tentu mendatangkan konflik. Anggapan agama mayoritas dan penduduk asli menjadi faktor penghalang terciptanya kerukunan umat beragama. Indikator kerukunan umat beragama tersaji dalam makna teoritis-nya. Dimana kerukunan umat beragama adalah keadaan hubungan sesama umat beragama yang dilandasi toleransi, saling pengertian, saling menghormati, menghargai keseta- raan dalam pengamalan ajaran agamanya dan kerja sama dalam kehidupan bermasyarakat. Seharusnya nilai-nilai kerukunan umat beragama ini tertanam kuat di dalam diri setiap pedagang kaki lima. Baik itu padagang kaki lima Kristen maupun pedagang kaki lima Islam.

Fanatisme agama cenderung berdampak negatif. Bahkan dapat menyebabkan bahaya konflik berkepanjangan di masyarakat. Herbert Schumann dalam ulasannya mengatakan:

Pendirian setiap agama bahwa merekalah yang empunya tawaran paling baik dan berkenan pada Allah sehingga paling cocok bagi manusia. Pandangan tentang kemutlakan itu senantiasa mengundang ketegangan dan pertentangan, bahkan konflik fisik, di antara persekutuan-persekutuan keagamaan. Sejarah umat Islam dan Kristen penuh dengan catatan mengenai bentrokan di antara mereka yang dijiwai oleh rasa kemutlakan itu. Tidak bisa disangkal, dan tidak perlu disangkal, bahwa rasa kemutlakan itu memang merupakan pegangan dalam setiap agama. Seseorang yang sungguh-sungguh percaya pada pesan keagamaannya dan menghayati-nya dengan tulus hati tidak akan meragukan kebenaran dan kemutlakan agamanya. ${ }^{15}$

Ulasan Schumann di atas sangat mendasar. Dimana fanatisme agama dapat memecah kerukunan umat beragama. Hal ini pun dapat terjadi di antara pedagang kaki lima Islam dan

15 Herbert Schumann, AgamaAgama: Kekerasan dan Perdamaian (Jakarta: BPK Gunung Mulia, 2015), 498. 
pedagang kaki lima Kristen di kota Kupang apabila fanatisme agama ini berkembang tidak sehat. Terlebih yang biasa menjadi korban adalah kaum minoritas yang dalam hal ini pedagang kaki lima Islam.

Seiring berjalannya waktu, hubungan pedagang kaki lima Islam dan pedagang kaki lima Kristen semakin lebih baik. Kesadaran untuk hidup rukun bersama semakin meningkat. Terlebih kesadaran membuang jauh-jauh sikap fanatisme yang berlebihan. Tentu kesadaran hidup rukun yang tumbuh dalam diri setiap pedagang kaki lima ini terbentuk dan tak lepas dari upaya serta peran tokohtokoh agama dan pemerintah setempat.

\section{Upaya Pencegahan Konflik Sosial}

Upaya-upaya pencegahan konflik sosial yang terjadi dalam penelitian ini merupakan hasil refleksi peneliti dan meramunya dengan beberapa teori yang telah dibahas di atas. Permasalahan dan konflik yang terjadi antara pedagang kaki lima Islam dan pedagang kaki lima Kristen yang telah dibahas dalam penelitian ini dapat teratasi dari beberapa upaya berikut ini:

Pertama, peran pemerintah setempat. Pemerintah setempat yang dimaksud adalah kepala daerah kota Kupang dan juga kepala daerah provinsi Nusa Tenggara Timur. Secara lokasi dan tempat berjualan pedagang kaki lima yang Islam maupun Kristen berada di jalan El Tari kota Kupang dan sekaligus berada di depan rumah jabatan gubernur provinsi
Nusa Tenggara Timur. Sudah tentu kondisi aman dan damai sangat diharapkan terjadi di sepanjang lokasi ini. Untuk itu, pemerintah kota Kupang dan juga pemerintahan provinsi Nusa Tenggara Timur tak henti-henti untuk terus mengkampanyekan dan menyerukan hidup rukun dan menjaga toleransi kepada masyarakat. Seruan ini dapat disimak dari beberapa peristiwa berikut ini.

Seruan dari pemerintah kota Kupang dalam hal ini Walikota Kupang. Koran Timor Express edisi Sabtu, 20 Mei 2017 halaman 9 dalam judul artikel "Jonas: Jaga Kerukunan, Jangan Pandang Mayoritas-Minoritas." Artikel ini memuat informasi bahwa Walikota Kupang Jonas Salean dalam rangka menjelang bulan Ramadhan, ia mengajak warga untuk menumbuhkan sikap toleransi antar sesama dan antar sesama umat beragama. Ia berharap agar warga kota semakin mempererat dan mempertahankan kerukunan dan persatuan antarumat beragama. Jangan sampai persaudaraan yang terjalin terpecah-belah dengan berkembangnya isu-isu yang bersifat provokatif serta jangan memandang mayoritas dan minoritas.

Seruan senada diungkapkan oleh pemerintah provinsi NTT. Timor Express edisi Minggu, 4 Juni 2017 halaman 9 dalam judul artikel "Pemerintah dan Masyarakat NTT Tolak Radikalisme." Artikel ini memuat informasi bahwa Gubernur NTT Frans Lebu Raya memimpin ikrar tolak radikalisme. Hal ini terkait dengan kondisi dan situasi nasional yang akhir-akhir ini 
berpotensi mengancam sendi-sendi kerukunan, persatuan dan kesatuan bangsa. Melalui tokoh agama, tokoh masyarakat dan seluruh elemen masyarakat membacakan ikrar menolak radikalisme. Dalam ikrarnya, pemerintah dan masyarakat menyatakan komitmen setia kepada Pancasila, UUD 1945, Bhineka Tunggal Ika dan NKRI. Mendukung aparat kepolisian dan TNI menindak tegas paham, gerakan dan ormas radikal masuk NTT sebagai wujud kehadiran Negara dalam menjaga dan menjamin keamanan masyarakat.

Seruan dari kepala daerah dan pemerintah di atas menjadi penegas bahwa kerukunan umat beragama dan toleransi sangat penting untuk ditegakkan dan diimplementasikan oleh masyarakat. Pesan dan seruan pemerintah di atas berdampak positif dalam kehidupan masyarakat dan juga pedagang kaki lima. Sehingga sampai saat ini tidak terjadi permasalahan dan konflik yang serius terjadi di kota Kupang.

Kedua, peran tokoh-tokoh agama. Tokoh-tokoh agama juga memiliki peran yang sangat penting dalam menciptakan kerukunan umat beragama dan toleransi di kota Kupang. Hal ini terkait dengan pembinaan rohani dari setiap pemeluk agama. Dimana tokoh agama dipandangan umatnya adalah tokoh yang berpengaruh dan sangat disegani. Umat umumnya cenderung lebih tunduk dan taat kepada pememimpin atau tokoh agamanya. Berdasarkan kondisi tersebut, tokoh agama menjadi salah satu pilar yang dapat memperkokoh persatuan dan kerukunan umat beragama yang ada di masyarakat.

Peran tokoh agama ini dapat terlihat dalam setiap dialog dan kerja sama yang terjalin di kota Kupang. Dimana tokoh agama Islam maupun Kristen giat dalam membangun dialog bersama untuk menciptakan kerukunan umat beragama yang ada di kota Kupang. Hal ini tercermin dari forum komunikasi umat beragama yang aktif dan terus berjalan sampai saat ini. Forum komunikasi umat beragama inilah menjadi salah satu wadah dimana para tokoh agama dapat membangun dialog dan kerja sama untuk mewujudkan masyarakat yang harmonis dan rukun.

Ketiga, peran masyarakat dalam mewujudkan kerukunan umat beragama. Peran masyarakat untuk mewujudkan kerukunan umat beragama juga menjadi bagian penting dalam upaya mengatasi konflik sosial. Peran masyarakat ini dapat ditunjukkan dengan prinsip-prinsip berikut ini:

a. Memperkuat hubungan kekeluargaan.

Prinsip kekeluargaan menjadi bagian penting dalam hidup bermasyarakat. Prinsip kekeluargaan yang dimaksud adalah setiap warga Negara adalah keluarga yang hidup di negeri ibu pertiwi negeri Bhineka Tunggal Ika yaitu Indonesia. Dengan prinsip ini diharapkan tidak ada lagi konsep yang membeda-bedakan satu dengan yang lain. Kebersamaan hidup rukun dalam kerangka keluarga 
Indonesia adalah cita-cita hakiki dan harapan bersama.

b. Saling memahami satu dengan yang lain.

Prinsip saling memahami satu dengan yang lain juga bagian penting dalam mewujudkan kerukunan umat beragama dalam masyarakat yang majemuk. Terdapat perbedaan karakter dan perilaku di masyarakat. Sikap saling memahami perlu untuk terus dipupuk dan direalisasikan dengan arif. Prinsip ini menjadi modal yang kuat dalam kelangsungan hidup bermasyarakat.

c. Memahami budaya dan tradisi setempat.

Prinsip memahami budaya dan tradisi setempat merupakan aspek penting yang tidak boleh dilupakan dalam mewujudkan kerukunan hidup beragama dan bermasyarakat. Secara khusus bagi masyarakat pendatang yang berada di tengah-tengah masyarakat lokal. Masyarakat lokal memiliki budaya dan tradisi yang berbeda dengan masyarakat pendatang. Untuk itu, masyarakat pendatang perlu untuk memahami bagaimana budaya dan tradisi masyarakat lokal. Dengan pemahaman yang baik, diharapkan akan menciptakan keharmonisan dalam hidup bermasyarakat satu dengan yang lain baik bagi masyarakat pendatang maupun masyarakat lokal.

d. Memperkuat kontrol diri di masyarakat.

Prinsip memperkuat kontrol diri dalam hidup bermasyarakat juga tidak kalah penting dengan prinsip di atas. Memperkuat kontrol dan penguasaan diri menjadi aspek penting dalam mewujudkan kerukunan dalam masyarakat. Hal ini terkait dengan fakta pengamatan peneliti bahwa umumnya masyarakat lokal kota Kupang memiliki kontrol diri yang lemah. Kontrol diri yang dimaksudkan adalah dalam hal penguasaan emosi. Masyarakat lokal cenderung mengutamakan aspek emosional dalam menghadapi suatu permasalahan, sehingga cenderung terjadi perselisihan dan perkelahian. Kondisi ini tentu tidak baik dalam hidup bermasyarakat. Untuk itu, prinsip memperkuat kontrol diri juga penting untuk diperhatikan oleh setiap masyarakat yang ada di kota Kupang.

\section{PENUTUP}

Dinamika kehidupan pedagang kaki lima Islam yang menjual bubur kacang hijau dalam penelitian ini dapat digambarkan dengan keadaan turun-naik. Artinya, ada masa-masa dimana pedagang kaki lima Islam dapat merasakan kenyamanan dan ketenteraman dalam berdagang, namun sebaliknya terdapat juga masa dimana mereka merasakan ketidaknyamanan dan ketidaktenteraman. Hal ini terkait dengan konflikkonflik kecil yang mereka alami.

Konflik yang terjadi antara pedagang kaki lima Islam dan pedagang kaki lima Kristen berawal dari rasa cemburu dan melebar 
sampai masalah ras, suku, dan agama. Hal ini terkait dengan kecemburuan pedagang kaki lima Kristen yang melihat keberhasilan pedagang kaki lima Islam dalam menjajakan dagangannya. Permasalahan ini tidak akan terjadi apabila pedagang kaki lima Kristen memahami dan mengimplementasikan dengan baik akan makna hidup toleransi dan kerukunan umat beragama. Akan tetapi karena tuntutan kebutuhan akan ekonomi dan keinginan yang kuat untuk berhasil berdagang namun belum tercapai, maka terjadilah kecemburuan sosial dan konflik.

Permasalahan dan konflik karena kecemburuan sosial ini tidak berlangsung lama. Pemerintah daerah dan tokoh-tokoh agama menjalankan peran mereka dengan baik dalam menciptakan keharmonisan dan kerukunan umat beragama dalam masyarakat. Dengan keharmonisan dan kerukunan umat beragama yang tercipta diharapkan masyarakat dalam hal ini pedagang kaki lima Islam dan pedagang kaki lima Kristen dapat menjalankan aktivitas berdagang dengan baik.

Pedagang kaki lima Kristen yang adalah penduduk mayoritas di kota Kupang seharusnya dapat menjalankan perannya dengan mengekspresikan dan mengimplementasikan prinsip kasih kepada sesama dengan baik. Prinsip ini penting dalam kehidupan bermasyarakat yang majemuk. Prinsip ini juga sejalan dengan harapan Schumann yang mencerahkan dengan uraiannya sebagai berikut:
Dalam bahasa keagamaan, tugas seorang Kristen dalam situasi seperti itu sama seperti pemenuhan tugas kenabian seseorang yang beriman dan membuka apa yang hendak disembunyikan. Ia bertugas memperjuangkan kebenaran, bukan membenarkan yang tidak benar. Ia pun tidak boleh diam jika ketidakbenaran membuat orang yang menderita berseru kepada Allah dan meminta pertolongan. Sebagai manusia yang beriman, seorang Kristen akan membawa perkara itu ke hadapan Allah, juga dalam doanya. Sebagai seorang anggota masyarakat dan warga negara, ia menggunakan sarana yang tersedia dalam lembaga duniawi itu untuk menuntut agar kebenaran ditegakkan. ${ }^{16}$

\section{DAFTAR PUSTAKA}

Ahmad, Haidlor Ali. 2014. Resolusi Konflik Keagamaan di Berbagai Daerah. Jakarta: Badan Litbang dan Diklat Puslitbang Kehidupan Keagamaan.

Ahmadi, Abu. Sosiologi Pendidikan. Jakarta: Rineka Cipta, 2007.

Kamus Besar Bahasa Indonesia. 2005. Jakarta: Balai Pustaka.

Kustini dan Syaiful Arif. "Kekristenan dan Nasionalisme di Kota Bogor." Jurnal Harmoni No. 2 Volume 15 (Jakarta: Puslitbang Kehidupan Keagamaan Badan Litbang dan Diklat Kementerian Agama RI Mei-Agustus 2016): 105.

Lauer, Robert H. 2001. Perspektif Tentang Perubahan Sosial. Jakarta: Rineka Cipta.

16 Schumann, Agama-Agama: Kekerasan dan Perdamaian, 308. 
Lubis, M. Ridwan. "Pengambangan Kebijakan Nasional dalam Pengelolaan Kerukunan," Jurnal Harmoni Volume 15 No. 2 (Jakarta: Puslitbang Kehidupan Keagamaan Badan Litbang dan Diklat Kementerian Agama RI Mei-Agustus 2016): 9.

Narwoko, J. Dwi dan Bagong Suyanto. 2005. Sosiologi Teks Pengantar dan Terapan. Jakarta: Kencana Prenada Media Group.

Schumann, Herbert. 2015. Agama-

Agama: Kekerasan dan

Perdamaian. Jakarta: BPK

Gunung Mulia.

Setiadi, Elly M. dan Usman Kolip. 2011. Pengantar Sosiologi Pemahaman Fakta dan Gejala Permasalahan Sosial. Jakarta: Kencana Prenada Media Group.

Sugiyono. 2016. Metode Penelitian Pendidikan Pendekatan Kuantitatif, Kualitatif, dan $R \& D$. Bandung: Alfabeta, 2016.

Susanto, Astrid. 2006. Pengantar Sosiologi dan Perubahan Sosial. Bandung: Bina Cipta.

Tirtosudarmo, Riwanto, dkk. 2010. Dinamika Sosial di Perkotaan Pantura dan Implikasinya Bagi Indonesia Studi di "Banten" dan "Demak". Jakarta: LIPI Press.

Turmudi, Endang. "Melihat Kembali Radikalisme Islam di Indonesia dan Upaya-Upaya Pencegahannya," Jurnal Masyarakat dan Budaya Volume 14 No. 2 (PMB-LIPI 2012): 223.

Website:

https://id.wikipedia.org/wiki/P edagang Kaki Lima diakses tanggal 04 Agustus 2017. 